\title{
Management of State Universities of Bahia Woman, Memory and Social Representations
}

\author{
Josias Benevides da Silva ${ }^{1}$, Luci Mara Bertoni ${ }^{2}$ \\ ${ }^{1}$ Bahia State University, Guanambi, BA, Brazil \\ ${ }^{2}$ State University of Southwest Bahia, Vitória da Conquista, BA, Brazil \\ Correspondence: Josias Benevides da Silva, Bahia State University, Guanambi, BA, Brazil.
}

Received: June 16, 2021

doi:10.11114/ijsss.v9i5.5264
Accepted: July 8, $2021 \quad$ Available online: July 16, 2021

URL: https://doi.org/10.11114/ijsss.v9i5.5264

\begin{abstract}
In this research, were analyzed the collective memory and social representations of women who are former rectors of the Public State Universities of Bahia, about the relations of power and gender in university management. The methodology of is qualitative research, through semi-structured interviews and observation, the material obtained was analyzed with Content Analysis. We can mention clashes, debates, support, focused on academic formation and the provision of services to society. As results of this study, it was observed that relations of power and gender in universities follow the logic of patriarchal society, with the difference that the knowledge, sometimes, inhibits or hides stigma and discrimination.
\end{abstract}

Keywords: university management, power relations, women, memory, social representations

\section{Introduction}

Power relations in state public universities in the State of Bahia has been structurally inserted in the same patriarchal logic observed in contemporary capitalist society. From the historical construction of gender roles, there is a greater presence of men in the occupation of university rectory positions, similar to what occurs in other social structures.

In management of Bahias universities, specifically the state public ones, only six women occupied the position of rector (five elected by the vote of the academic community), in more than three decades of existence of these institutions, a reality out of line with the fair distribution of power, if we consider the large contingent of women who make up Bahian society, especially in the faculty of public universities. The presented study proposes the following question: based on their narratives, what are the collective memories and social representations that women who were deans of State Public Universities in Bahia have about power relations and gender in university management?

Women's access to university rectory is permeated by political relations, inside and outside the institution, these political relations, as well as in other spaces of power in contemporary capitalist society, have been not only favorable to men, but were structurally projected and applied by and for them. In this context, women, when they are rarely elected to leadership positions, have been demonstrating the capacity for transparent and coherent management with the social objectives expected of a public institution, resulting, at least in a localized way, in the resolution of prejudices about the possible management of women at the spaces of power.

Based on this understanding, the study aimed to analyze the collective memory and the social representations of women former deans of the State Public Universities of Bahia, with regard to power and gender relations in university management.

The methodology of this study is qualitative in nature. To collect the data, semi-structured interviews were used with the five former deans of the State Public Universities of Bahia, from August 2017 to February 2018. In addition to the semi-structured interviews, observations were also made during the electoral process to chose rectors of the State University of Bahia (SUBA), in 2017, and of the State University of Southwest Bahia (SUSWBA), in 2018.

\section{Gender and Feminism: Some Conceptions}

The term gender refers to a cross-cutting analytical category, comprising the masculine and feminine, man and woman, male and female of the human species, which goes through the different sexualities (heterosexual, homosexual, transsexual, among others) and expressions, in their biological, cultural, historical and socially situated perspectives, 
which questions the ideologies, discriminations, inequalities and patriarchal power ${ }^{1}$ (Freitas, 2018). This category concerns the way(s) of being and being in the world and it's part of the social, historical and cultural relations of human beings in their search for survival, which connects it to economic and political relations and, consequently, to relations of power.

Gender is, therefore, a concept within the historical and cultural construction, socially coined by various theories that stand against inequalities for reasons of sex genre, class, ethnicity, religion, among others, especially when the feminine is put as inferior to the masculine and, thus, the legitimation of the supremacy of the latter over the former. "From this angle, gender is inscribed in the plane of history, although it can never be seen in a definitive way separated from sex gender, as it is also inscribed in nature [...]" (Saffioti, 2015, p.144).

In Brazilian context, according to Norma Kyriakos (2007), from the Federal Constitution of 1988, known as the "Citizen Constitution", gender equality has been sought, based on the experience of social well-being, in which rights human beings replace the practices of violence and the ethics of the feminine look at the global and the local begins to transpire in social relations. However, the author warns that there is a considerable distance between what the law says and what is actually practiced: "An advanced legislation and a backward practice is our reality" (Kyriakos, 2007, p. 19). Historically exploited and oppressed, women receive less protection from the labor laws, regarding the differences in salaries, working hours and working conditions, when compared to men, being denied their own citizenship (Costa \& Sardenberg, 2008).

By presenting the definitions of gender above, in its complexity, transversality and different shades, the concept of feminism is also understood as a category that requires care when presenting it, given its complex and multifaceted nature.

For more than two centuries, women have been organizing (in a systematic way) and fighting for gender equality in different places around the world. Even in sexist and authoritarian societies, there are records of women's uprisings that, through literature, art, politics, religion, science or other human actions, claim their rights to be and be in the world on even earlier dates to the nineteenth century, as Varela explains:

Feminism is a political discourse that is based on justice. Feminism is a theory and political practice articulated by women who, after analyzing the reality in which they live, become aware of the discrimination they suffer for the sole reason of being women and decide to organize themselves to end with these discriminations, to change society [...] From this reality, feminism is articulated as a political philosophy and, at the same time, as a social movement [...] Besides being a political theory a social practice, feminism is much more. Discourse, reflection and feminist practice also carry an ethic and a way of being in the world [...]. (Varela, 2013, p. 14-15).

As examples of feminine articulations prior to the advent of feminism as a category of academic study, it is possible to cite the work of Chistine de Pizan, La ciudad de las damas, written in 1405, which already dealt, in a certain way, the issues of feminism. "She is the first recognized woman writer, also endowed with great polemic capacity which allowed her to intervene in the literary debates of the moment" (Varela, 2013, p. 24). This was followed historically by the work of Mary Wollstonecraft entitled Vindicación de los derechos de la mujer, from 1794, considered as the initial milestone of feminism in the world.

Regarding the definition of the actions of people who identify themselves with feminism, Joana Pedro (2013) states that it is about the one who sees women as having the same professional capabilities as men, not tolerating discrimination or gender/sex violence, who advocates for women's sexual pleasure as it is for men, and for equal rights between men and women.

In Brazilian context, feminism, especially at the turn of the 19th to the 20th Century, with the advent of the Republic, expanded its struggle and achievements. As some of the milestones of feminist political conquest in Brazil, we can mention Myrthes de Campos admission to the Brazilian Bar Association in 1906, being the first woman to be part of this organization. In 1910, Leolinda Daltro founded the Women's Republican Party and organized a march in favor to women's suffrage. In November 1917, in Rio de Janeiro, in addition to the aforementioned women, Bertha Lutz and other feminists also played a leading role in the struggle for civil and democratic rights of Brazilian women (Soihet, 2013).

According to Pierucci (2007), the feminist movement in Brazil can be understood from three distinct waves ${ }^{2}$ : egalitarian,

\footnotetext{
${ }^{1}$ According to Saffioti (2015) patriarchy is a form of male power and domination over females, therefore a gender issue that must be discussed.

${ }^{2}$ It is understood by wave, in feminism, specific generations of women who organized fight for rights movements.
} 
differentialist and women's multiplicity. "The intellectual history of feminism unfolds in three main stages. These are the so-called three waves of feminist theorizing, its three major advances in defining its object of struggling" (Pierucci, 2007, p. 31). In the late 1980s, feminism in Brazil reached its complexity and multiplicity in the triad of gender, race/ethnicity and class.

Although feminism (theoretical/academic) in Brazilian context has relied on intellectual and higher economic class women, especially to write theory about feminism and represent it in national and international spaces, popular feminism has been very important for the expansion and unification around social, political and economic rights of Brazilian women, including black feminism, which relies on worker and academic movements, inside and outside universities (Nepomuceno, 2013).

The theories of gender and feminism and their related practices have denounced for centuries the privileges of some at the expense of the denial of rights for many. Among the privileged are, mainly, rich white men, while the majority who have their rights denied are women and other clippings of gender, ethnicity and class who find themselves on the margins of society. This is a current reality in various sectors of society, including the university, even though it is a producer of knowledge in gender studies and a denouncer of violence and inequalities.

\section{Power Relations and University Management}

Power is inherent in human relationships and, as such, is present in public and private institutions in the different sectors of human work. Thus, within university management, in which genders relate, in a hierarchical chain, with different departments and functions, power manifests itself, sometimes authoritarianly, sometimes in a democratic and participatory way. About this, it is understood that "Every legal order (not only the "state" one), by its configuration, directly influences the distribution of power within the community in question, both economic and any other" (Weber, 1999, p. 175).

Regarding the mechanisms that influence the manifestation and maintenance of power, Foucault $(1979$, p. 8) theorizes that "what makes power maintain and be accepted is simply that it does not weigh only as a force that says no, but that in fact it permeates, produces goods, induces pleasure, forms knowledge, produces discourse".

For Butler (2017, p. 21), "[...] assuming power is not an easy task for removing it intact and immediately appropriating it, the act of appropriation may involve a alteration of the power that enabled it to be assumed [...]". And Hannah Arendt ([1906-1975] 2018) adds that power is only effective through word and deed, without which it cannot survive.

Thus, power is inherent in the act of governing. To govern, in turn, is to establish management. The etymology of the word management comes from the Latin (gerere) and means to govern, conduct, direct (Oliveira, 2005). "Management is, then, the activity by which means and procedures are mobilized to achieve the organization's objectives" (Libâneo, 2007, p. 318).

To govern, in a political vision, is also to manage programs and projects to meet social demands and needs, using resources from taxes paid by the population. The various state institutions consolidate public management, based on the direction of the federal, state and municipal governments. These concepts, to a greater or lesser extent, also apply to academic management.

In the current context, the academic community (teachers, students and technicians) and society in general expect the University, especially the public one, to be open, inclusive, democratic and participatory. This institution, which emerged in Europe in the 11th Century, as stated by José Dias Sobrinho (2007), is an institution of diversity, complexity, multiple facets and is, by definition, multi-referential.

For Matos (2004), the university is an institution that embraces not only diversity, but also complexity. This complex institution has multiple purposes that are planned, executed, evaluated and fed back in teaching, research and extension. Just in extension, for example, the variety of actions ranges from services provided in social areas to cultural activities, serving the most different social classes.

The higher education system in Brazil currently follows the national norms foreseen in the Federal Constitution of 1988, pursuant to article 207 which states: "The universities have didactic-scientific, administrative, as well as financial and

Initially, the so-called first wave, in 17th, 18th and part of 19th centuries, was centered on the struggle against slavery (slavery abolition), followed by the second wave around civil and political rights, around, at the end of 20th century and first half of 21st century; and, finally, at mid-twentieth century to the presente day, several struggles composse the third wave, such as the right to abortion, rights and respect for minorities (LGBTQIA+), the right to be free and procriation, ecology, among other movements. 
patrimonial management autonomy, and will obey the principle of inseparability between teaching, research and extension" (Brazil, 1988).

Besides the determinations about higher education in Brazil defined in the Federal Constitution of 1988, the Law of Guidelines and Bases of National Education n.9,394/96 (Brazil, 1996), in articles 52 to 57, deals with the definition, role, responsibilities, autonomy and sources of resources for their respective didactic-pedagogical, technical-scientific and related activities.

The State Universities of Bahia (SUBAs) are part of the public university system, a system comprising four universities, two of which are multicampuses: State University of Bahia (SUBA) and State University of Southwest Bahia (SUSWBA); and two uniCampus: State University of Feira de Santana (SUFS) and State University of Santa Cruz (SUSC). Together, they are responsible for serving more than sixty-four thousand Higher Education students in the State of Bahia (IPEA/2017) and thousands more in postgraduate studies. Although considered as young universities, they have national and international recognition for the relevant academic, technical, scientific and social service they have offered over the last few decades. It is on this universe, therefore, that our investigation is located.

\section{Collective Memory and Social Representations Theory: Praxis of Everyday Relations}

In human groups, including higher education professionals, collective memories and social representations (SR) are constituted, which account for human relationships in their daily practice, as explained below.

According to Halbwachs (1990), the strength of collective memory is in the group of men, although they individually also have their memory, but each individual memory, which makes up the whole of collective memory, changes depending on the place that the man occupies and the relationships established within the group. For the author, there are in each society several collective memories, with different meanings, since the events are specific to a given group built in a certain space and time.

In Celso Sá's (2007) conception, any political discussion cannot be done without referencing the past. It is in the past, with influences in the present, that collective memories wage their clashes and, as it would not be different, it is in the public sphere that the relations between power and memory are most observed.

In turn, social representations, according to Serge Moscovici ([2000] 2003, p.46-47), “[...] should be seen as a specific way of understanding and communicating what we already know [...]; they are dynamic structures, operating in a set of behavioral relationships".

Thus, SRs are created from our coexistence in the world, in which we share reality with each other. "They guide us in the way of jointly name and define the different aspects of everyday reality, in the way we interpret these aspects, make decisions and, eventually, position ourselves against them" (Jodelet, 2001, p.11).

In this perspective, José Valencia (2005) states that Collective Memory, as well as SR, are interdisciplinary theories, since they dialogue with various scientific fields, such as psychology, anthropology, sociology, history, literature and many other areas of human action and reflection.

\section{Results and Discussion of Survey Data}

In the case specified here, the research participants belong to a group of women who were deans of the State Public Universities of Bahia, but also belonged, or still belong, to other groups, such as the teaching staff of their respective institutions, to family groups, where and when they constitute their collective memories, their existence and their social representations of the reality in which they live. These memories were collected from semi-structured interviews and analyzed using the Content Analysis method, as advocated by Laurence Bardin (1977).

In the performance of the former rectors of SPUBAs, the electoral process emerges in their collective memories and social representations, which discusses, among other things, the electoral campaign, the political support, both inside and outside the university, the elective plea, the correlations of force and power that we can summarize in two central words: clashes and partnerships. When elected and nominated, women begin their respective administrations, facing the university rectory, putting them to the test, in terms of their competence to govern and lead teams, whose terms that best define this trajectory are: challenges and accomplishments.

Although the reports of each former dean of the State Public Universities of Bahia were collected individually, it is not an isolated memory of each one, since each memory is intertwined with other memories, which were related in time and space of the narratives, as Halbwachs (1990) states, the strength of collective memory is in the group of human beings, even if they individually also have their memory, each individual memory, makes up the whole of collective memory, and modifies itself depending on the place it occupies and the relationships it establishes within the group.

About the memories that bring up issues of gender conflict, one of the interviewees, Professor Ivete Alves do Sacramento (former dean of SUBA, in the period from 1998 to 2005), reported that her vice-rector, through his speech 
and actions, several times showed disrespect and discriminated her, mainly in relation to her gender and race/ethnicity. The discredit to her competencies, among other issues, led him to become Sacramento's direct opponent in the dispute for the rectorship in the following term. About the demonstrations of racism and machismo made by the candidate for the rectorship, Sacramento comments:

And on the last day of debate, which was on Campus One, in his speech, he made an analogy between a vulture and me. And when I resumed the speech, I said that he had the wrong bird; he saw a black bird and he was mistaken, as it was not a vulture, but an eagle and represented renewal and persistence for renewal. (Sacramento, on 10/24/2017).

In this speech, racial discrimination is evident, even in so-called "civilized" spaces and with advanced academic training still, especially in disputes of power, racism and discrimination come to the fore. In this excerpt, there is clearly a process of anchoring, as presented by Moscovici (2003), when we find an analogy between the black and the vulture, in a racist demonstration, as well as in the analogy of the eagle with power and strength.

Still on the subject of electoral campaign, Professor Renée Albagli Nogueira, former dean of Santa Cruz State University (1996-2004), begins by talking about the motivations that led her to run for the rectory of SCSU, among which she mentions her participation in the administration of the Federation of Higher Schools of Ilhéus and Itabuna: "[...] I held positions in the university administration, including as appointed vice-rector. This is the taste I always had for public management. It's a matter of vocation. So I thought I should face this challenge" (Nogueira, on 12/05/2017).

Common to the trajectory of other candidates for the rectorship of Public Universities in the State of Bahia, Anaci Bispo Paim also held administrative positions before running for a position as dean of SUFS, such as coordination of collegiate, directorships and president of administrative committees and the implementation of undergraduate and graduate courses. "[...] this gave me a much closer view of the institutional reality, with regard to final activities, because I started having the opportunity of direct leadership in the academic area" (Paim, on 02/05/2018).

The importance of the previous occupation of administrative positions and/or proximity to the intra- and extra-academic community, ocurs in the sense that the election campaign, whether inside or outside the university, requires articulation and adherence to the collective management project. Power is exercised in relationships and therefore requires agreements, achievements, adhesions, because, as stated by Butler (2017, p.21) "[...] to assume power does not consist the easy task of removing it intact and immediately appropriating it, the act of appropriation may involve a change in the power that enabled it to be assumed [...]".

Still on the campaign for the rectorship of SPUBAs, at the time of Yara Maria Cunha Pires' mandate as the dean of SUFS, the university had recently made the transition from the Faculty of Education and Philosophy of Feira de Santana to the State University of Feira de Santana, a change in which the professor actively participated.

I didn't feel like facing it, but it was a very difficult moment politically, because it was the year of the first direct election for governor, in 1986. We were coming out of the dictatorship, and the first election for state government. So you imagine all the repressed demands for democracy and for everything! For all the needs that existed. (Pires, on 02/06/2018).

In turn, professor Adélia Maria Carvalho de Melo Pinheiro admits that electoral processes, inside or outside the university, are not easy. Within these large groups cited by the professor, there was a permanent dialogue in search of the right profile to be a candidate for the rectory of SUSC, and she was the one who gathered the necessary characteristics to run for this position at that time. The memory of a social group certifies itself as a group (Halbwachs, 2004).

In her talk about the different leaders who supported her during the campaign and their respective administrations, besides to the gender component, the race/ethnicity component is evident when she mentions African and Afro-American political figures as important supporters of her mandate, an emphasis given by teacher Ivete Sacramento as a mark of her identity and as a social representation of a certain group.

Still on difficulties and support during her tenure as rector of SUFS, professor Yara Cunha reports the challenges faced, given the political, social and economic context that Brazil was going through, with high inflation and wage losses.

Centrally, in the collective memory and social representations of the former deans interviewed, the support to sustain a candidacy and develop a satisfactory management, inside and outside the university, is of fundamental importance. Initially, because without empathy and conquest, partnerships are not made and, therefore, the candidate ends up not being someone known (and recognized) enough to be chosen as the group's representative.

In this same perspective of supports, the research participants' social representations of political relations, in the university and beyond, are seen as vitally needed, as explained, for example, in the report by Pires (2018). 


\section{University Management}

Whether uniCampus or multicampuses, the complexity of managing a public university is challenging. Facing the challenge of university management requires a range of skills and abilities from the person leading the team. In the case of the university, the dean, whether male or female, is required to have a dense education and proven experience, in addition to a good work team. Without the support and co-organized work with other people, the managers are not able to do a good job on behalf of the community, which benefits from the services provided by a Higher Education institution, in its triad: teaching, research and extension.

In the words of professor Ivete Sacramento, university management is a great challenge, especially when it comes to a multicampi university, as is the case of SUBA, with a territorial occupation of more than $800 \mathrm{~km}$, in the State of Bahia. "But at the time we were the only multicampi university in the state and one of the few multicampi in Brazil. A management model that was criticized. When I took over the management at SUBA, everything was centralized here on Campus One" (Sacramento, on 10/24/2017). As stated by Nez (2016), the multicampi University not only has a differentiated structure, but, above all, it reserves a wealth of particularities in its functional and space-time dimension that makes it unique.

In the conception of Professor Renée Nogueira, the strategic basis for building a university is people. The university, according to her, must respect and create conditions fot the diversity and plurality of ideas to be present in academic activities, but in a dialogical posture around common goals, in favor of a public service. "The university, it should house all ideological currents, so it stands out in its social responsibility, which is the power it has to, let's say, criticize, discern, guide, educate, this is the role of the university" (Nogueira, on 12/05/2017).

In the report of Professor Anaci Paim, during her administration, she defined more effectively the administrative structure of SUFS, which became more similar to the structure of other universities in the country. "While we were creating this whole situation of improving institutional projects, the space was insufficient and the big challenge was this, to expand the physical spaces of the university [...] The university's challenges change their appearance, but they are permanent and continuous, because an institution in full growth does not have an engineer to finish the work at the university, it is an unfinished work, it reveals the time of men" (Paim, on 02/05//2018).

The memory of what a university is includes its space, time and relationships. As Halbwachs (1990) states, memory and space are durable and stable enough to not age and not lose their constitutive parts, thus remaining as marks of memories and recollections.

Before the administration of Professor Anaci Paim, Professor Yara Cunha narrates that SUFS was one of the first universities in the country to have a new departmental Campus model, in the 1970s. According to her, unfortunately, there is a lot of vanity and a lot of disputes within the university, which makes hinders collective work towards a common objective, which is to serve the population that depends on the services of this institution. So, these disputes within institutions are micro power relations understood here as "[...] the probability of a person or several imposing, in a social action, their own will, even against the opposition of other participants" (Weber, 1999, p. 175).

Within SUSC, in the words of professor Adélia Pinheiro, there has always been a gender balance in the institution's management and that in the rectory, women have had more mandates than men. Other prominent social representations in the memory of former deans are related to knowledge: knowing how to be, knowing how to do, knowing, are necessary elements for the dean or dean of a public university. Knowledge, just like the university itself, is unfinished and is acquired by several means: by experience in the daily routine, by education, and by living together inside and outside the university.

In the memories and social representations of the former deans, among what they bring about the achievements and the challenges of their respective administrations in state public universities in Bahia, education and training of people, from undergraduate and postgraduate courses deserve to be highlighted, graduation in-service training through several courses, allied to research and extension, as permanent spaces for personal and professional improvement.

The way of governing democratically, respecting participation, autonomy and collective decisions is also present in the social representations of the research participants. They believe that power must be diluted and shared, since the university project is a collective project, aimed at the public good of all for all. Therefore, they do not admit an authoritarian and centralizing management.

In this way, the former deans talk about what it is to be a woman, their role as protagonists in the management of universities, and about the gender inequality still present in our society.

When you are a woman, you suffer discrimination that other people, who are men, think you will not succeed. I think there were many people who got scared, who thought they were going to manipulate me [...] So, there is this issue that women are more fragile, and people are surprised when you have more energy in certain situations. 
(Sacramento, on 10/24/2017).

The social representation of women as the weaker sex makes them, in the realms of ideas, an unprotected being who needs male guardianship to present themselves in public space. For, as stated by Guacira Louro (2006, p. 454) "The feminine fragility, constituted by the religious, medical, legal and educational discourse is also part of their protection and tutelage", which does not seem to be part of the experiences of former deans of SPUBAs.

Professor Renée Nogueira, in turn, says that the 1990s were a favorable period for women to occupy management positions in the State of Bahia, including in the State Public Universities: in her management, for example, the team was almost entirely formed by women.

Being a woman means facing the social stigma of the provider of the home, the "queen of the home", the "mother of the family", the one who takes care of the house, the children, the husband and even the parents, the place of passivity. "But it is a mistake to pretend that this is a biological given: in fact, it is a destiny imposed on her by her educators and by society" (Beauvoir, 1967, p. 21).

As Professor Renée Nogueira says: "[...] this is a cultural issue, a secular issue, the woman did not occupy the space she occupies today in society, she was educated to be the mother in the family. We all know that for women to occupy these spaces in politics was also procedural, it is something more recent" (Nogueira, on 12/05/2017).

In the context of SUFS, professor Anaci Paim reports that she never had problems being a woman and that her academic career developed naturally, through effort, competence and recognition of her peers, including in management positions. The fact of being a woman, according to Paim, was not an obstacle in her administration, on the contrary, in many moments, the gender issue was a positive factor in her thinking and acting within the university's administrative sphere. This is supported by the second wave of feminism when the gender difference is a positive mark that should be highlighted in favor of women (Pierucci, 2007).

In a management team formed practically by women, during Iara Cunha's administration in front of the SUFS rectory, she reports that there was, at least visibly, no gender discrimination on the part of her male colleagues. The subtlety with which these questions are posed, especially when women are in senior positions, is, in fact, almost invisible, but there are strategies that, consciously or unconsciously in memory and social representations, men put them into practice to exercise power mechanism (Ambrosini, 2017).

Professor Iara comments that being a woman manager is not easy, because in addition to the activities developed in the institution she manages, she still takes care of home, even though she is the dean of a university. Thus, we saw in Varela (2013) that the division of domestic tasks is fundamental for the reduction of machismo and female emancipatory evolution."When I took over the rectory, my children were already raised, the youngest was 13 years old, for me it was no problem, but we know that for a woman with a baby it's difficult, because I didn't have time to get there, sometimes I worked until ten o'clock at night" (Pires, on 02/06/2018).

Not only being a woman, but what women do is different from what men do, according to Adélia Pinheiro: "With that, I recognize that there is a different way of doing men and women in management positions, anywhere, in the world of work and in the social, personal world. There will always be a difference and it is not natural, but it is historically and socially constructed. My understanding is that this is a qualifying tool for women's participation in management positions" (Pinheiro, on 12/06/2017).

One way or another, the research participants agree that there are gender inequalities in the world of work, especially in executive and management positions in public and private institutions, even though they often do not recognize concrete actions related to this.

In practice, we suffer from the gender issue, it is not as much as the racial issue, but it is present. [...] Sometimes, people are surprised because they enter the room and see a black woman. They don't expect me to be dean, ever! Same thing with the race issue; when you combine race and gender in one person, it's a problem. (Sacramento, on 10/24/2017).

According to Matos (2010), in addition to the condition of the female gender, black women suffer because of the condition of their race, which is why Ivete Sacramento highlights her ethnic awareness and the constant manifestations of racism she suffered as a university manager, mainly.

It is notorious the value that these women, who were deans of the State Public Universities of Bahia, give to formal education, as a necessary condition for women to exercise power inside and outside the university. Through education, according to Louro (2006), since the beginning of the 20th century, women have ben organizing themselves and demanding more and better education, as a way to promote female independence, following the example of the militant and revolutionary Nísia Floresta (1810-1885). 


\section{Data from the Electoral Process of Suba (2017) and Suswba (2018)}

Even if there are not always, as noted in the previous section, reports from former women deans indicating the presence of actions that demonstrate gender inequality, it is important to realize that, structurally, these differences can still be frequent.

In the patriarchal perspective, in which the power of the male gender seeks to subjugate the female, especially in leadership positions in public spaces of society, in Brazilian politics, it is observed that, even with the law of quotas (Law $\mathrm{n}^{\circ} 12.034 / 2009$ ), which institutes a minimum of $30 \%$ and a maximum of $70 \%$ for candidacies of each sex (female and male), this percentage is not fulfilled and, when it is, women are hardly elected, especially in senior legislative and executive positions in politics.

About this predominance of the male gender, in the positions of deans of the University of the State of Bahia and of the State University of Southwest of Bahia, when we count the choice by direct vote of the academic community, there are 18 male and 02 female administrations. The SUBA, from 1983 to 2020, in its thirty-seven (37) years of existence, had only one woman in the rectory for eight (08) years, representing $21.6 \%$ of the management occupied by the female gender. In the case of SUSWBA, it has been in existence for thirty-nine years, with only one woman in charge (through the government's nomination and not by the choice of the academic community's vote) for four years, as we saw in table four (04).

As already presented, the presence of women in the rectorships of SUBA and SUSWBA is lower than that of the SUFS which, in forty-four (44) years of its existence, has had women rectors for three terms, professor Yara Cunha Pires for one term and professor Anaci Paim for two terms totaling twelve years of management. Of the four universities, however, the best (numerical) balance of male and female genders in the rectory is at SUSC, which in its 25 years of existence has had two female rectors, elected and reelected, completing sixteen years of mandate, representing $64 \%$ of female management against $34 \%$ of male management. In the sum of the SPUBAs, the female gender represents $27 \%$ of the rectory period, which is little, and therefore it is very representative of the Brazilian situation in general, including other spaces of power, such as the legislative houses of the country.

During 2017 and 2018, the authors of this study followed the elections for the choice of dean of the State University of Bahia (SUBA) and of the State University of Southwest Bahia (SUSWBA), in order to verify the mechanisms for the choice in relation to the female and male genders. After the calendar of the entire electoral process for choosing representatives to the SUBA rectory, on 10/04/2017 the elections were held, with the following results:

The "We are All SUBA" ticket, made up of the rector seeking reelection and the vice-rector, obtained $64.46 \%$ of the votes in that election and was nominated by the governor. A similar result at SUSWBA: the men's "Renew SUSWBA: another university is possible" ticket had the highest percentage of votes, $61.09 \%$, which was elected and nominated.

Coincidence or not, these two cases presented here, as well as the history of elections for deans of the State Public Universities of Bahia, as already presented, resembles the logic of elections in the national political sphere, in which the main executive, legislative and judiciaries of our institutions, especially the presidencies of the legislative and judicial houses, have historically been occupied by men.

\section{Concluding Remarks}

The former rectors agree on the issue of belonging to the female gender: at least for them, it was not an obstacle to reach the rectory of the State Public Universities of Bahia and exercising their respective mandates, even aknowledging that, in society, in general, gender inequality is noticeable. In this sense, power relations are maintained with respect and collaboration within the hierarchy. Somehow, belonging to the female gender worked as a positive factor, as observed in the interviews.

Another issue on which the former deans are in agreement is that public, free and quality education is a preponderant factor in achieving high positions of power at the university and having a successful career. In the literature on feminism, in Brazil and in the world, education has been listed as a phenomenon of paramount importance in the emancipation of women since the past centuries.

Finally, about what it means to be a woman and the management of higher education, the social representations of the former deans reveal that the female gender can, despite the negative characterization it has received during history, assume a positive, different, strong and determined potential, even recognizing that these social representations are not the same as those that predominate in our society.

We can say that regarding the memory and social representations of the former SUBAs rectors, what is most evident about the electoral process, which comprises the period from the formation of slates to the ratification of the results, are the clashes and partnerships, while in management itself, at the center of representations, are the challenges and the 
achievements.

Thus, if on the one hand conflicts and clashes are remarkable, on the other hand, so are support and partnerships. The electoral process brings out affections and disaffections in the dispute between male candidates and female candidates, similar to what happens in national politics. Even in the academic sphere, discriminatory attitudes of gender and ethnicity still exist, according to the reports of the women interviewed.

We conclude that women's political competence is very important in the negotiation process within organizations. It takes competence to lead people: to dialogue, to defend ideas, to listen, to speak, to reject, to accept, to retreat. To form a team with political commitment and scientific and didactic-pedagogical competence capable of transforming reality and performing functions that the institution requires, both in teaching, as well as in research and extension, is also very important. Not having women in the management of government spheres and in the management of public institutions, such as universities, constitutes a form of devaluation of feminine competencies demonstrated in all other sectors of universities. Without them, Brazil delays its condition as a sustainably developed nation, with great damage to people's lives, accentuating inequality of gender, race/ethnicity and class.

\section{References}

Ambrosini, A. B. (2017). The representation of women as deans and Vice-Rectors of Federal Universities in Brazil: A Quantitative Study. XVII International Colloquium on University Management. Mar del Plata- Argentina. Retrieved from https://repositorio.ufsc.br/xmlui/handle/123456789/181013

Arendt, H. [1906-1975] (2018). The human condition. Trans. Roberto Raposo; ver. eaps. Adriano Correia. (13nd ed.) ver. Rio de Janeiro, RJ: University Forensics. https://doi.org/10.7208/chicago/9780226586748.001.0001

Bardin, L. (1977). Content Analysis. Lisbon (Portugal): Editions 70.

Beauvoir, S. (1967) The second sex: the lived experience. (2nd ed.) v. 2. Trans. Sergio Milliet. São Paulo, SP: European Book Diffusion.

Brazil. (1988). Constitution of the Federative Republic of Brazil. Ministry of Education. Ministries Esplanade. Brasilia. Federal District.

Brazil. (1996). LDB - Law of Directives and Bases of National Education - Text in full Law 9394 of December 20, 1996. Editora Saraiva.

Butler, J. (2017). The Psychic Life of Power: Theories of Subjection. Trans. Roger Bettoni. Belo Horizonte, BH: Authentic Publisher.

Costa, A. A. A., \& Sardenberg, C. M. B. (2008). Feminism in Brazil: theoretical reflections and perspectives. Salvador: Federal University of Bahia / Center for Interdisciplinary Studies on Women.

Dias, S., \& Preface, J. (2007). In MARBACK GRANDSON, Guilherme. Assessment: university management instrument. Vila Velha, ES: Hoper Publisher.

Foucault, M. (1979). Microphysics of power. Org. and Trans. Roberto Machado. Rio de Janeiro, RJ: Graal Editions.

Freitas, M. A. (2018). Women scientists: paths and setbacks from the reality of Federal University of Minas Gerais. Belo Horizonte BH: Knowledge Bookstore and Distributor.

Halbwachs, M. (1990). Collective memory. (2nd ed.) Trans. Laurent Léon Schaffter. São Paulo, SP: Revista dos Tribunais Magazine LTDA.

Halbwachs, M. (2004). Social frameworks on memory. Trans. Manuel A. Baeza and Michel Mujica. Rubí (Barcelona): Anthropos Editorial; Conception: University of the Concepción; Caracas: Central University of Venezuela.

Institute for Applied Economic Research [IPEA]. (2017). In 10 years, the reduction of extreme poverty was at least $63 \%$. Retrieved from http://www.ipea.gov.br/portal/index.php?option=com_content\&view=article\&id=2700

Jodelet, D. (2001). Social representations: an expanding domain. In: JODELET, Denise. (Org.). Social representations. Lilian Ulup. Rio de Janeiro, RJ: EDUERJ.

Kyriakos, N. (2007). The history of feminism in Brazil. In: BRABO, Tânia Suely Antonelli Marcelino. (Org.). Gender and education: past struggles, present achievements and future perspectives. São Paulo, SP: Icon, 2007. pp. 17-29.

Libâneo, J. C. (2007). School education: policies, structure and organization (4th ed.) São Paulo, SP: Cortez.

Louro, G. L. (2006). Women in classroom. In: DEL PRIORE, Mary (Org.) E BASSANZI, Carla. (Text Coordinator). History of women in Brazil. (8nd ed.) São Paulo, SP: Contexto, 2006. pp.443-481.

Matos, M. (2010). Feminist Movement and Theory: Is It Possible to Reconstruct Feminist Theory from the Global South? 
Rev. Sociol. Polit., Curitiba, 18(36), 67-92. https://doi.org/10.1590/S0104-44782010000200006

Matos, M. T. N. B. (2004). Institutional Memory and University Management in Brazil: the case of the Federal University of Bahia. Doctoral thesis. Federal University of Bahia, Salvador, 2004, $184 \mathrm{f}$.

Moscovici, S. (2003). Social representations: investigations in social psychology. Edited in English by Gerard Duveen; translated from English by Pedrinho A. Guareschi. Petrópolis, RJ: Voices.

Nepomuceno, B. (2013). Black women: leading role ignored. In: PINSKY, C. B. \& PEDRO, J. M. (Orgs.). New History of Women in Brazil.eBook. São Paulo, SP: Context, 2013. Chap.17.

Nez, E. (2016). The Dilemmas of Multicampi Universities Management in Brazil. GUAL Magazine, Florianópolis, 9(2), 131-153. https://doi.org/10.5007/1983-4535.2016v9n2p131

Oliveira, M. A. (2005). Educational management: new views, new approaches. Petrópolis: Voices.

Pedro, J. M. (2013). "Second Wave" Feminism: body, pleasure and work. In: Pinsky, Carla Bassanezi \& Pedro, Joana Maria (Orgs.). New History of Women in Brazil.eBook. São Paulo: Context, 2013. Chap. 11.

Pierucci, A. F. (2007). From egalitarian feminism to differential feminism and beyond. In Brabo, T. S. A. M. (Org.). Gender and education: past struggles, present achievements and future perspectives. São Paulo: Icon, 2007.

Sá, C. P. (2007b). On the field of study of social memory: a psychosocial perspective. Psychology: Reflection and Criticism, V.20, p. 290-295. https://doi:10.1590/198053143133

Saffioti, H. (2015). Gender patriarchy violence. (2nd ed.) São Paulo, SP: Popular Expression: Perseu Abramo Foundation.

Soihet, R. (2013). Women's Movement: The Conquest of Public Space. In: Pinsky, C. B. \& Pedro, J. M. (Orgs.). New History of Women in Brazil.eBook. São Paulo, SP: Context, 2013. Cap.10.

Valencia, J. F. (2005). Social representations and social memory: vicissitudes of an object in search of a theory. In: Sá, Celso Pereira de. Memory, imaginary and social representations. Rio de Janeiro, RJ: Museum of the Republic.

Varela, N. (2013). Feminism for beginners. Barcelona (Spain): Non-fiction.

Weber, M. [1864-1920] (1999). Economy and society: foundations of comprehensive sociology. Translated by Regis Barbosa and Karen Elsabe Barbosa. Brasília: Editora Universidade de Brasília: São Paulo: I

\section{Copyrights}

Copyright for this article is retained by the author(s), with first publication rights granted to the journal.

This is an open-access article distributed under the terms and conditions of the Creative Commons Attribution license which permits unrestricted use, distribution, and reproduction in any medium, provided the original work is properly cited. 